\title{
THE 2015 MIGRATION CRISIS IN THE EUROPEAN UNION AS A NON-TRADITIONAL SECURITY CHALLENGE
}

\author{
Katarzyna Marzęda-Młynarska \\ Uniwersytet Marii Curie-Skłodowskiej w Lublinie \\ Wydział Politologii, Zakład Stosunków Międzynarodowych \\ e-mail:marzedak@wp.pl
}

\begin{abstract}
The article analyzes the 2015 migration crisis in the European Union from the perspective of Non-Traditional Security (NTS) Challenges. It argues that the current wave of immigration to the EU, due to its dynamics and scale, should be treated not only as a humanitarian or social challenge but also as a security one. The value of the NTS approach is based on the assumption that well-known phenomena such as illegal migration, infectious diseases, or food shortages, which once had only an indirect influence on national or international security, now pose direct threats to the survival and well-being of peoples and states.
\end{abstract}

Key words: Non-Traditional Security Challenges, migration crisis, European Union

\section{INTRODUCTION}

The old Chinese proverb says: 'May you live in interesting times,' but it is not a 'good luck' wish, but rather a curse based on a perception of change as a threat to stable, predictable, and peaceful times, what might be described as a time of crisis. Looking at the situation within the European Union (EU) in the second decade of the 21 st century, it is hard to resist the impression that a completely new reality is emerging, shaped by the unpredictability and immense dynamics of change. In such new circumstances, the ability to recognize and interpret those changes is limited as is the ability to take proper actions to address them. Old phenomena, such as migration, gain a new face that is difficult for decision-makers who have been stuck in old interpretations to understand.

The European Union is changing. The most noticeable changes occur in the sphere of security. The perception of the EU as an oasis of stability and security is no longer the case. In the second decade of the 21 st century, the illusion of 
a Europe without conflicts is over, due to the Donbas conflict, the migration crisis and terrorist attacks. The individual perception of being safe is changing, too. More EU citizens feel fear and danger than ever before. According to an April 2015 Eurobarometer survey, before the migration crisis and terrorist attacks in Paris and Brussels, $27 \%$ of respondents totally agreed with the statement that the EU is a secure place to live, and 52\% tended to agree. ${ }^{1}$ A spring 2016 survey conducted by the Pew Research Center, revealed, however, that, due to the migration crisis and fears about terrorism, almost $60 \%$ of citizens in ten EU member states believed incoming refugees and immigrants contributed to a deterioration of security. ${ }^{2}$

The aim of this article is to analyze the migration crisis in the EU from the perspective of the Non-Traditional Security (NTS) concept, ${ }^{3}$ which offers a new analytical perspective on the changing nature of threats to states' security. It is based on an assumption that well-known phenomena such as illegal migration, infectious diseases or food shortages that once had only an indirect influence on security, now pose direct threats to the survival and well-being of peoples and states. ${ }^{4}$ The study argues that, due to its dynamics and scale, the current wave of immigration to the EU should be treated not only as a humanitarian or social challenge but also as a security one.

The article consists of four parts. The first briefly explains the essence of the 2015 migration crisis. The second concentrates on the theoretical model of Non-Traditional Security Challenges. The third analyzes the European migration crisis in terms of Non-Traditional Security Challenge. The final section is devoted to the EU response to the 2015 migration crisis.

1 EC, Special Eurobarometer Survey: Europeans' attitudes towards security, MEMO Brussels, 28 April 2015, URL: <https://ec.europa.eu/home-affairs/sites/homeaffairs/files/e-library/ documents/basic-documents/docs/20150408_1_memo_eurobarometer_april_2015_v2_en.pdf', [access 1.03.2017].

2 R. Wike, B. Stokes, K. Simmons, Europeans Fear Wave of Refugees Will Mean More Terrorism, Fewer Jobs. Sharp ideological divides across EU on views about minorities, diversity and national identity, Pew Research Centre 2017, URL: <http://www.pewglobal.org/2016/07/11/ europeans-fear-wave-of-refugees-will-mean-more-terrorism-fewer-jobs/>, [access 1.04.2017].

3 M. Caballero-Anthony, Non-state regional governance mechanism for economic security: the case of the ASEAN Peoples'Assembly, "The Pacific Review" 2014 17(4), pp. 567-585. Idem, Non-traditional security and infectious diseases in ASEAN: going beyond the rhetoric of securitization to deeper institutionalization, "The Pacific Review" 2008, 21(4), pp. 507-525, Idem, Non-Traditional Security challenges, regional governance and the ASEAN Political Security Community (APSC), “Asia Security Initiative Policy Series" 2010, Working Paper no 7, Singapore; Idem (ed.), Introduction to the Non-Traditional Security Studies. A Transnational Approach, London 2016, Sage Publications; M. Caballero-Anthony, R. Emmers, A. Acharya, Non-traditional Security in Asia: Dilemmas in Securitization, London 2006, Ashgate.

4 R. Emmers, Globalization and Non-Traditional Security Issues: A study of human drug and human trafficking in East Asia, Institute of Defense and Strategic Studies Working Paper no 62, 2004, Singapore. 


\section{THE ESSENCE OF THE 2015 MIGRATION CRISIS IN THE EU}

According to the International Organization for Migration (IOM), the term "migration crisis' "describes the complex and often large-scale migration flows and mobility patterns caused by a crisis which typically involve significant vulnerabilities for individuals and affected communities and generates acute and longer-term migration management challenges". ${ }^{5}$ What is more, a "migration crisis may be sudden or slow in onset, can have natural or man-made causes, and can take place internally or across the border". ${ }^{6}$

The definition identifies the four elements of a migration crisis--scale, scope, speed, and results--that distinguish it from ordinary migration flows. It suggests that migration flows can easily transform themselves into migration crises due to the rapidly-growing flow of migrants, observed in one time and in one place, that are hard to control and manage and often extend beyond national borders.

The links between migration and crisis need to be clarified, however. Two approaches can be identified. In the first, migrations are treated as an effect and the crisis as a cause, i.e., crisis situations, that is conflicts or natural catastrophes lead to massive migration. This linkage reflects the perspective of states which "generate" migrants. In the second approach, the linkage is reversed, the cause is migration and the effect is crisis; massive migration leads to the crisis, understood as an inability to effectively control and manage the massive inflows of people. This linkage reflects the perspective of host states that are unable to accept all migrants, to ensure their protection regardless of their status, or to satisfy their needs by providing them with basic goods (shelter, education, health care, jobs, etc.).

The migration crises in the EU illustrates the second approach. It is not about migration per se but the inability of affected states to manage and control unprecedented inflows of illegal migrants. The crisis in this context means a situation in which states are confronted with acute and long-term migration management problems. They are not prepared, ready, nor equipped to manage it effectively.

The 2015 migration crisis in the EU illustrates the four elements of the International Organization for Migration definition: scale, scope, speed and results.

The scale. More than one million people arrived to Europe and over a million and a half have applied for asylum in $2015 .^{7}$ According to the IOM data, total arrivals to Europe in 2015 slightly exceeded one million and reached $1046599 .{ }^{8}$ According to a Frontex report, however, the number of detections of illegal en-

5 International Organization for Migration, IOM Migration Crisis Operation Framework, MC/2355, 15 November 2012, p. 1-2.

6 Ibidem, p. 2.

7 International Organization for Migration, Mixed Migration Flows in the Mediterranean and Beyond, Reporting Period 2015, URL: http://doe.iom.int/docs/Flows\%20Compilation\%202015\%20 Overview.pdf, [access 12.04.2017]; Eurostat News Release 44/2016, 4 March 2016, URL: http:// ec.europa.eu/eurostat/documents/2995521/7203832/3-04032016-AP-EN.pdf/, [access 12.04.2017].

8 International Organization for Migration, Mixed Migration..., op. cit. 
tering into EU territory in 2015 increased six fold: from 282962 people in 2014 to 1822337 in $2015 .{ }^{9}$ Frontex statistics are based on member states' detections of illegal border-crossing on the EU external border and include all attempts to enter EU territory illegally. In some cases, this meant more than a one thousand per cent increase in migrant inflows, especially from Syria, Afghanistan and Iraq. ${ }^{10}$

The scope. The massive inflow of migrants in 2015 was a particular burden to only some EU member states, those located at the EU external borders of the most popular migration routes and those chosen as destination or asylum claims countries. Due to the fact that the largest number of migrants have entered EU through the Eastern Mediterranean and Western Balkan route, the massive influx of immigrants has been a particular burden for Greece, Italy, and Hungary, where migrants first arrived. According to the International Organization for Migration, more than 850 000 immigrants arrived to Greece, more than 150000 to Italy and more than 400 000 to Hungary in $2015 .{ }^{11}$ This placed enormous pressure on immigration services and contributed to many social, economic and political issues. The next group of countries where the migration crisis became particularly visible were destination and asylum claim states. According to Eurostat, there were over 1.2 million asylum applications in EU in 2015 compared to 560000 in $2014 .{ }^{12}$ The highest number of first time applicants per million inhabitants in 2015 were recorded in Hungary - 17 699, Sweden - 16 006, Austria - 9 970; and Germany - $5441 .{ }^{13}$ In absolute numbers, the biggest number of applicants in 2015 was recorded in Germany - over 400 000, in Hungary - over 170 000, and in Sweden - over $150000 .{ }^{14}$

The speed. The massive inflows of immigrants to the EU was unexpected even though the signs of it were observed in many part of the EU. While during the first five months of 2015, from January to May, the situation was about the same as in 2014, it changed dramatically in June 2015. During the following months, the number of immigrants increased rapidly, peaking in October 2015. While the outbreak of the crisis is associated with the German Chancellor's September 2015 decision to allow free movement for all migrants to chosen EU states, the negative trends were observed by June 2016, when the number of immigrants doubled. Within the next three months it was clear that the rapid inflows of migrants was not a temporary situation that could be prevented by existing policies and regulations but the beginning of a migration crisis. According to IOM statistics, the crisis revealed itself during several months in 2015, and its speed surprised most of the affected countries as well as EU institutions. The dynamic of the EU migration crisis is illustrated below.

9 Frontex, Annual Risk Analysis 2015, s. 17, URL: http://frontex.europa.eu/assets/Publications/ Risk_Analysis/Annual_Risk_Analysis_2015.pdf, [access 12.04.2017].

\footnotetext{
${ }^{10}$ Ibidem.

${ }^{11}$ International Migration Organization, Mixed Migration..., op. cit.

${ }^{12}$ Eurostat News Release 44/2016..., op. cit.

${ }^{13}$ Ibidem.

${ }^{14}$ Ibidem.
} 


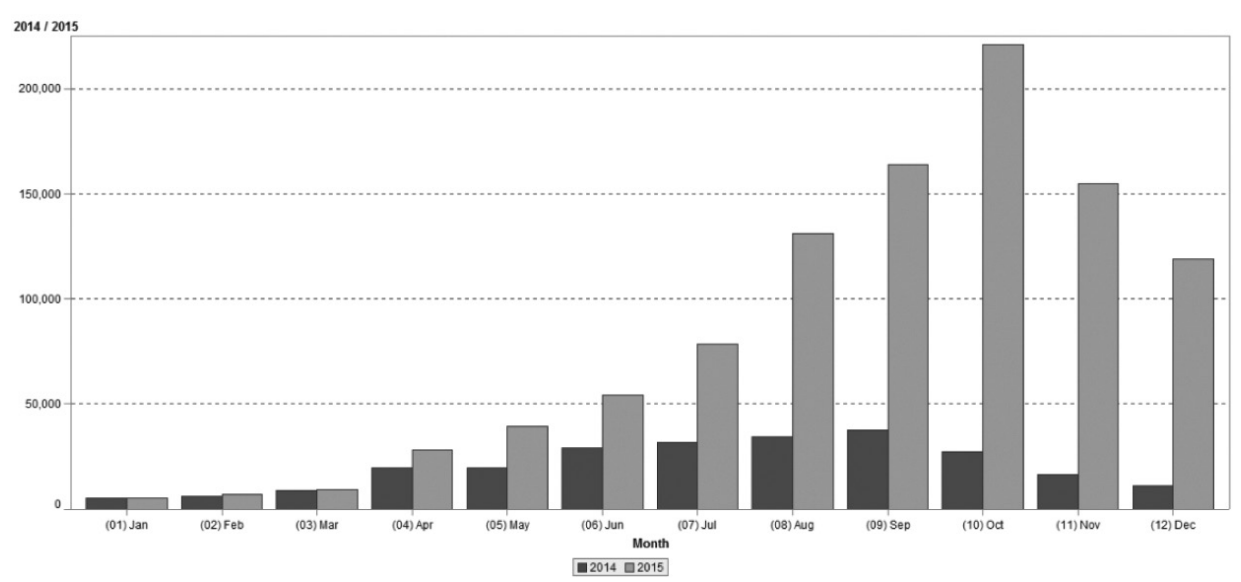

Picture 1. Arrivals to Europe by month in 2015 versus 2014

Source: International Migration Organization, Mixed Migration Flows in the Mediterranean and Beyond, Reporting Period 2015, URL: http://doe.iom.int/docs/Flows\%20Compilation\%202015\%20Overview.pdf, [access 12.04.2017].

The results. Member states and EU institutions were both caught by surprise and unprepared for the unprecedented inflow of people. The results of the 2015 migration crisis can be divided into two categories: those for the affected states and those for the entire EU. For the individual member states, the migration crisis meant physical influx of immigrants, followed by problems with providing them with food, water, shelter, and other social services. The sudden influx of people has generated high costs, especially for the first arrival states such as Greece, Italy and Hungary. It has revealed the lack of preparation of immigration services paralyzed by the 'flood' of asylum applications and an inability to identify and register all who were crossing the borders. Chaos and improvisation are the best characterizations of the actions taken by individual states in the face of the crisis. The situation stabilized, yet new problems have emerged: social tensions, terrorist attacks and increased violence and crime. At the EU level, the migration crisis has exposed a number of problems: from effective external border protection, through asylum procedures, and the ending of the Schengen Agreement on the internal free movement of people.

In sum, the essence of the 2015 migration crisis in the EU was rooted in the rapid influx of people at, resulting in the inability of individual member states as well as the EU to effectively cope and apply all procedures prescribed by law.

\section{THE NON- TRADITIONAL SECURITY CHALLENGES CONCEPT AS THEORETICAL MODEL}

The literature on NTS argues that non-traditional security challenges such as climate change, resource scarcity, infectious diseases, natural disasters, illegal migrations, food shortages, people smuggling, drug trafficking and transnational 
crime, ${ }^{15}$ have a non-military source but can, under specific conditions, be transformed into direct security threats. While this is not a completely new discovery - according to Mely Caballero-Anthony, the NTS concept "shares conceptual spaces" 16 with comprehensive and human security - the NTS concept adds some new elements to those approaches. In brief, it links non-military phenomena such as illegal migration, starvation, organized crime, diseases, climate change directly to traditional security by emphasizing that they pose a direct threat to the survival and well-being of peoples and states.

In the NTS perspective the difference between traditional and non-traditional security is situated in the source of existential threats. While traditional security is understood in terms of military threats that stem from competition between states or a shift in the balance of power, non-traditional security emphasizes the non-military character of it. ${ }^{17}$ However, both military and non-military challenges can result in the same outcome - the likelihood of conflict or war. What is more, the NTS concept assumes that non-traditional threats cannot be effectively eliminated without a certain level of multilateral cooperation. A single state's capacities are not enough to effectively deal with transnational, quickly arising problems, so multilateral cooperation becomes necessary.

The NTS concept also offers an 'analytical methodology' designed to recognize the non-traditional security threats among the many phenomena and problems faced by states. It is based on five assumptions: first - the non-traditional challenges could lead directly to conflict or war. Second - the narrow state perspective is inadequate for dealing effectively with NTS challenges. Third -states as well as communities and individuals are actors responsible for ensuring security. Fourth - threats such as climate change or pandemics are transnational in nature and require non-military responses. Fifth - due to the transnational character of these challenges, international cooperation is essential. ${ }^{18}$ There are also six distinctive characteristics of non-traditional security threats:

- they have a transnational character understood in terms of their origins, conceptions, and effects;

- they are defined in political and socioeconomic terms;

- they cause societal and political instability and become security threats;

- their effects are difficult to reverse or repair;

- they require regional and multilateral cooperation due to the inadequacy of national solutions;

${ }^{15}$ M. Caballero-Anthony, Understanding Non-traditional Security, [in:] M. Caballero-Anthony (ed.) Introduction to the Non-Traditional Security Studies. A Transnational Approach, Sage Publications, London 2016, p. 6.

${ }^{16}$ Ibidem, p. 13.

${ }^{17}$ Ibidem, p. 15.

${ }^{18}$ Ibidem. 
- they constitute a threat to both states, their territory and sovereignty, and peoples, individuals and societies. ${ }^{19}$

As an analytical concept the NTS approach includes six research steps organized around answers to the following questions: first, how is the problem perceived and do all involved actors perceive it the same way? Second, who are the actors involved, whose interests do they represent, and what are those interests? Third, whose security is involved (nation-states, global security, regional security, human security)? Fourth, how was the threat identified and how has its interpretation changed? Fifth, what kind of actions were taken to solve the problem (resources allocation, legislation, institutionalization)? Sixth, what is the impact of those actions on the problem. ${ }^{20}$ The fourth part of this study will apply this methodology to the EU's response to the 2015 migration crisis.

\section{THE MIGRATION CRISIS IN THE EU AS A NON-TRADITIONAL SECURITY CHALLENGE}

Four of the six characteristics of non-traditional security will be thoroughly discussed in the case of the EU migration crisis: transnational character, political and socioeconomic dimensions, security threat, and the inadequacy of national solutions.

There is no doubt that the 2015 migration crisis has a transnational character. In the simplest interpretation, massive inflows of migrants from war zones such as Syria and Iraq, unstable and oppressive regimes such as Afghanistan, Pakistan, or poor and underdeveloped states such as Tunisia, Morocco and Nigeria, undermine the ability of destination and transit states to effectively control their borders. When confronted with the unprecedented scale of migration, national boundaries become irrelevant. The growing involvement of criminal organizations in people smuggling practices makes it even more difficult. According to Rob Wainwright, Director of Europol, about $90 \%$ of the migrants who arrived to Europe in 2015 used services provided by criminal networks. The earnings of people smugglers rose by $\$ 5$ to $\$ 6$ billion. ${ }^{21}$

The transnationalisation of the migration crisis means the problem becomes more and more 'transboundary and shared'. Neighbouring states, even those not treated as destination states, become increasingly involved in the problem as transit states and places for migrants' temporary stay. This situation was observed in states such as Hungary, Bulgaria, Serbia, Croatia, Slovenia, and Macedonia, which were located along the "Balkan route', and now in Greece and Italy, which are the EU's 'front line' states.

\footnotetext{
${ }^{19}$ Ibidem, p. 6.

${ }^{20}$ Ibidem, p. 16

${ }^{21}$ Europol, Interpol, Migrant Smuggling Networks. Joint Europol - INTERPOL Report, 2016, URL: https://www.europol.europa.eu/publications-documents, [access 12.04.2017].
} 
The transnational character of the migration crisis can also be illustrated by growing problems with the effective identification and determination of their status and appropriate protection. Their multiple identities, lack of identification with a single state or ethnicity, and reliance on family and friends rather than official institutions in host countries make it difficult to control and manage the huge inflows of people. A striking example is the situation in Germany, where over one million migrants arrived in 2015, and whose authorities did not know where as many as 130000 asylum seekers were. ${ }^{22}$ What is more, many host countries, including Great Britain, Denmark, Germany, France, Belgium and the Netherlands, have experienced the emergence of informal migration-based transnational networks that circulate capital, goods and ideas, and are out of the control of national authorities as a result of the massive inflow of migrants. These kinds of networks played a critical role in terrorist attacks in Paris in 2015 and in Brussels in 2016.

The next characteristic of non-traditional security threats is their political and socioeconomic nature. The roots of the current irregular migration wave are multidimensional, yet most analysts agree that the main reason is "the failure of the international community to address conflicts, violence and human rights violations of countries of origin". ${ }^{23}$ Analysis of the characteristics of states from which most migrants came is very informative. Syria and Iraq are states steeped in war, so the vast number of migrants from those states seeking entry to Europe are fleeing conflict and violence in their home countries. ${ }^{24}$ Although most of the war migrants from Syria and Iraq found protection in neighbouring states such as Turkey, Jordan, and Lebanon, the deterioration of living conditions there and the lack of prospects as well as active propaganda by smugglers and traffickers persuaded many refugees move on to Europe.

The other leading sending states, Afghanistan, Somalia, South Sudan, Eritrea, Central African Republic, Mali, Nigeria, Pakistan, Iran, Tunisia, and Morocco, are facing not only constant violence, conflict and poverty but also rapid population growth that results in a large number of young people, many of whom have no prospects for the future. Easy access to information on the Internet, where potential migrants can find out how their peers in Europe live, accelerates the decision to leave. The ambiguous policy of European states towards migrants, e.g., allowing of border law violations and selective border controls, gives the smugglers and potential migrants good arguments to continue their trip to Europe and contributes to the deepening of the crisis.

${ }^{22}$ BBC News, Germany reports disappearance of 130000 asylum seekers, URL: http://www. bbc.com/news/world-europe-35667858, [access 12.04.2017].

${ }^{23}$ V. Metcalfe-Hough, The migration crisis? Facts, challenges and possible solutions, The Overseas Development Institute Briefing, October 2015.

${ }^{24}$ Ibidem, p. 2. 
Non-traditional security threats are also considered as threats to traditional security, understood in terms of the likelihood of conflict and war, ideas of territory and sovereignty, and the protection of basic national interests. There are many studies in which the problem of migration is treated as a security threat. ${ }^{25}$ It can be analyzed from international ${ }^{26}$ and national perspectives, ${ }^{27}$ however, as Fiona Adamson points out, "The general impact of migration on national security depends on the efficacy of particular state's policy to shape migration flows according to its overall national interests". ${ }^{28}$

Anna Kicinger identifies six components of security that might be threatened by international migration and its consequences:

- social stability - in terms of the rise of xenophobia and lack of integration;

- demographic security - in terms of higher fertility rates characteristic of migrant populations compared with the population of the host state;

- cultural identity - in terms of compromises between the host countries' and migrants' traditions and culture;

- social security system and welfare policy - in terms of increased spending on migrants and the reluctance of residents to pay for it;

- internal security - in terms of rising crime levels, organized crime, human trafficking and terrorism. ${ }^{29}$

Fiona Adamson analyzes the migration - security nexus using three perspectives. The first concentrates on state capacity and autonomy. She argues that large-scale migrant inflows can result in:

- undermining a state's capacity to provide public services;

- growing probability of conflicts over resources;

- increasing political mobilization of migrant societies and the emergence of "refugee-warrior communities";

- growing activity of organized criminal networks;

${ }^{25} \mathrm{~W}$. Anioł, Migracje międzynarodowe a bezpieczeństwo europejskie [International Migrations and European Security], Instytut Studiów Politycznych Polskiej Akademii Nauk, Warsaw 1992; F.B. Adamson, Crossing Borders. International Migration and National Security, "International Security" 2006, 31(1), pp. 165-199; A. Kicinger, International Migration as a Non-traditional security threat and the EU responses to this phenomenon, CEFMR Working Paper 2, 2004; S.O. Wolf, The Rohingya: Humanitarian Crisis of Security Threat, "The Diplomat" 2015, URL: http:/ thediplomat.com/2015/10/the-rohingya-humanitarian-crisis-or-security-threat, [access 10.06.2016].

${ }^{26}$ W. Anioł, Migracje międzynarodowe a bezpieczeństwo europejskie [International Migrations and European Security], Instytut Studiów Politycznych Polskiej Akademii Nauk, Warsaw 1992; A. Kicinger, International Migration as a Non-traditional security threat and the EU responses to this phenomenon, CEFMR Working Paper 2, 2004.

${ }^{27}$ F.B. Adamson, Crossing Borders. International Migration and National Security, "International Security" 2006, 31(1), pp. 165-199; S.O. Wolf, The Rohingya: Humanitarian Crisis of Security Threat, "The Diplomat" 2015, URL: http:/thediplomat.com/2015/10/the-rohingya-humanitarian-crisis-or-security-threat/, [access 10.06.2016].

${ }^{28}$ F.B. Adamson, Crossing Borders..., op. cit., p. 168.

${ }^{29}$ A. Kicinger, International Migration as a Non-traditional security threat..., op. cit., p. 2. 
- reshaping national identity;

- questioning established patterns of national identity which can lead to the internal instability and incoherence,

- creating new transnational identity communities,

- transnationalisation of political participation that can impair a state's ability to formulate coherent a foreign policy. ${ }^{30}$

Adamson's second perspective addresses the problem of migration and the balance of power. As she emphasizes, migration policy can be used by states as a tool to exercise their national interests. Wise migration policy can enhance a state's power, however, the opposite can compromise it. What is more, the deliberate stimulation of large migrant waves and streaming them to particular states works as a political tool serving interests of other states. ${ }^{31}$

The third perspective addresses the problem of the changing nature of violent conflicts. According to Adamson, migration flows can contribute to violent conflicts in three ways: by providing resources that help to fuel internal and international conflicts, by providing opportunities for networks of organized crime, and by providing conduits for international terrorism. ${ }^{32}$

The 2015 migration crisis in Europe undoubtedly posed a threat to traditional security. The terrorist attacks in Paris and Brussels confirmed the growing risk of mass, illegal, and basically uncontrolled migration. The number of false asylum seekers, combined with high levels of illegal migration, make it easier for terrorists to enter Europe unchecked and to freely move across borders.

It is also argued that non-traditional security threats cannot be controlled by individual states and that multilateral cooperation is essential. In the context of the EU migration crisis, three types of multilateral cooperation - humanitarian, legal, and security - can be identified.

- Humanitarian - includes providing migrants with basic goods and satisfying their basic needs. The massive inflow of people creates logistical challenges that individual states were unable to bear. Existing laws and procedures impose special duties on host states to deliver certain goods and services to migrants and give them protection. The experiences of Hungary, Greece, Italy, Turkey, Jordan, Lebanon, show that the massive inflows of people exceed the capabilities of single states.

- Legal - includes providing migrants with protection according to their status. It requires sound institutions and procedures, adequate infrastructure such as registration centers, migrant facilities, and professional staff (migrant experts, border officers, police, medical service, interpreters, psychologists) in adequate numbers. Another need is access to information. The same person can register in different states and apply for financial

\footnotetext{
${ }^{30}$ F.B. Adamson, Crossing Borders..., op. cit., p. 175-185.

${ }^{31}$ Ibidem, p. 185-190.

${ }^{32}$ Ibidem.
} 
support from different states. The improvement of registration procedures, the stricter border control due to border police delegation, and growing information sharing between EU member states illustrate the cooperation in that area.

- Security - includes targeting illegal people smuggling practices and fighting against organized crime and terrorism. The transnational character of the migration crisis, understood as mobility across national borders, requires some level of international cooperation in areas such as information sharing, joint actions against human traffickers and smugglers, and joint actions against terrorism. Examples of multilateral cooperation between EU member states can be identified in this area.

These premises make multilateral cooperation necessary in the context of the migration crisis. It is difficult to determine, however, which premises are most important. Nevertheless, it is symptomatic that the states confronted with security problems are more eager to take decisive actions than those confronted only with humanitarian challenges.

\section{THE EUROPEAN UNION RESPONSE TO THE MIGRATION CRISIS}

While the migration crisis is an extraordinary situation that poses a challenge to regional institutions, the response to it depends on many factors. The analysis of EU response to the crisis will be organized around the methodology offered by the NTS concept, which includes six research steps concentrated around answers to the following questions:

- How was the problem perceived and have all involved actors perceived it the same way?

- Who were the actors involved, whose interests did they represent, and what were those interests?

- How was the problem identified, and how has the interpretation changed?

- What kind of actions, e.g., resource allocation, legislation, institutionalization, were taken to solve the problem?

- What was the impact of those actions on the problem?

\section{How was the problem perceived and have all involved actors perceived} it the same way?

The perception of the migration crisis in the EU changed from that of a humanitarian crisis to a solidarity issue to a security threat. Differences can be identified between the actors involved. Local authorities, NGOs, and civil society emphasized the humanitarian dimension - attempts to help to individual migrants. States had various perceptions: from humanitarian crisis (Germany, Sweden), logistical challenge (Italy, Greece, Serbia, Croatia, Denmark), security threat (Poland, Hungary, Bulgaria, Czech Republic, Slovakia). EU perceptions 
included humanitarian crisis, solidarity challenge, human rights violation and external border control.

Who were the actors involved, whose interests did they represent, and what were those interests?

Different actors located at different governance levels were involved in the governance of the European migration crisis. At the lowest level were local communities, focused on helping immigrants, e.g. 'willkommen' activists in Germany as well as communities protecting locals from immigrants e.g. "Soldiers of Odin" in Finland, self-organized migrant hunters in Bulgaria; humanitarian and human rights NGOs such as Medicines Sans Frontiers, Red Cross, Caritas; and local authorities responsible for accommodation and providing immigrants with basic human needs. At the national level, the most active actors were governments, which represented the interests of the states according to their political line. At the supranational level the most important actors were EU institutions, whose decisions and policies reflected the contradictory interests of member states. Those interests varied from solidarity and a true desire to help (NGOs, local communities, local authorities, some governments, e.g. Germany) through taking control over the migrant flows and fulfilling the Common European Asylum System (CEAS) obligations (Hungary, Bulgaria, Slovenia, Croatia, EU institutions) and safeguarding territory (Hungary, Bulgaria, Croatia, Austria, Sweden, Belgium, Germany, France. Slovakia, local 'migrant hunters'), to protecting external borders and fighting the causes of the migration crisis at its sources (most EU members, all EU institutions).

How was the problem identified, and how has its interpretation changed? At the beginning the migration crisis was perceived as a humanitarian problem that needed more decisive action in rescuing migrant boats. This interpretation dominated public discourse at the European and national level until the November 2015 terrorist attacks in Paris, when a new security' interpretation was added. At the national level, in most EU member states the problem was interpreted as a humanitarian challenge yet, from the beginning it was also viewed as a security challenge in some - Hungary, Czech Republic, Slovakia, and then later in Poland, Bulgaria, Denmark, Austria, and the Netherlands. The interpretation of the migration crisis has strongly polarized public opinion in most EU member states and raised support for anti-immigration movements.

\footnotetext{
What kind of actions were taken to solve the problem (resources allocation, legislation, institutionalization)?

At the EU level, the actions taken to solve the migration crisis concentrated on four issues: physical influx of immigrants, the problems of EU external border protection, asylum procedures according to CEAS, and maintenance of the internal free movement of people granted by the Schengen Agreement.
} 
In the case of the physical influx of immigrants, four types of action were taken: rescue operations aimed at boat migrants (The European Council emergency meeting 23 April 2015, Brussels); enhancing the European solidarity quota system aimed at helping the states where the largest groups of immigrants had arrived: Italy, Greece, Hungary (The European Commission proposition on quota scheme 11 May 2015); relocation mechanism aimed at smoothing the distribution of arriving immigrants between EU member states (The European Commission Packages of Proposals on relocation mechanism 27 May 2015; 9 September 2015; The European Council Decision on relocation of 40000 immigrants from Greece and Italy and 20000 from outside the EU, 26 June 2015; The Justice and Home Affairs Council on relocation of immigrants 20 July 2015 - 56 000, 14 September 2015 - 40 000, 22 September 2015 - 12 000); agreements with and support for third-countries (Informal Meeting of EU Leaders on emergency support to the UNHCR, WFP, Lebanon, Turkey, Jordan and Western Balkans 23 September 2015, EU - Africa Valletta Summit on Migration 12 November 2015, The EU-Turkey Joint Action Plan 29 November 2015, Trust Fund for Africa).

In the case of external border protection, actions taken concentrated on three problems: strengthening the EU's external border, regaining control of the external border, including effective fighting against people smuggling, and external border management, including effective registration of migrants and creating hotspots where migrants can be registered. On 15 October 2015, the European Council decided to strengthen the EU's external borders - including an integrated border management system that will go beyond the current Frontex mandate and the addition of hundreds of additional border guards to secure hotspot areas in Greece and Italy. The problem was discussed by the Justice and Home Affairs Council in November 9, 2015, at an Informal Meeting of the EU Leaders in November 12, 2015 where they discussed regaining control of the external border and effective registration of migrants. On February 18-19, 2016, the European Council decided to improve external border management, including the need to gradually get back to a situation where all members of the Schengen area fully apply the Schengen Borders Code, and to make hotspots fully functional. There was also discussion at the Justice and Home Affairs Council on creating a European border and coast guard. Its main objective would be to ensure and implement, as a shared responsibility, integrated border management at the EU's external borders. It would consist of a European Border Guard Agency and national authorities responsible for border management. Since the beginning of the migration crisis, the EU has initiated operations to fight against people smuggling. The EU action plan against migrant smuggling was adopted on May 27, 2015. On June 22, 2015, the EU launched the EUNAVFOR Med (later the Sophia operation) naval operation against human smugglers and traffickers in the Mediterranean. Part of the solution was an agreement with Turkey.

In the case of asylum procedures, the EU discussed reforming the Common European Asylum System. On April 6, 2016 the European Commission presented 
a project for reform that identified five areas where the CEAS should be changed: adoption of a distribution of migrants mechanism to insure fairness and solidarity in responsibility; replacement of the Asylum Procedures Directive and Qualification Directive with new regulations setting standards on asylum procedures to help eliminate asylum shopping, and preventing secondary movement within the EU by making certain rights conditional upon registration, fingerprinting, and staying in the country assigned to the applicant; broadening the European Asylum Support Office mandate by giving it new competencies in policy-implementing and operations (distribution mechanism, harmonization of standards); and reinforcing the Eurodac system. The negative reaction to the proposal expressed by some member states proved that there is strong opposition to the direction of the European Commission's reform proposal.

In the case of the maintenance of Schengen, the EU adopted internal border controls. On May 12, 2015, the Council of the EU adopted a recommendation that allows for the continuation of temporary internal border controls in exceptional circumstances. Austria, Germany, Denmark, Sweden, and Norway could maintain temporary border controls at specific parts of their borders for a maximum period of six months. The restoration of border controls by different European states due to the migration crisis puts the Schengen agreement into question.

Actions taken at the state level revealed changes in perception of the migration crisis from a purely humanitarian issue to a security problem. Most EU member states have undertaken actions aimed at stopping the immigrants' inflow, sending them back, or making their stay less attractive. The actions varied considerably. From an open-door policy represented by Germany, Austria and Sweden to imposing internal border controls (Germany, Austria, Sweden, Denmark, France), building fences (Hungary, Bulgaria, Austria), and sealing the borders (Austria, Croatia, Slovenia, Hungary, Bulgaria). From a 'willkommen' policy (Germany, Austria) to tightening asylum policy (Germany, Austria, Denmark, the Netherlands, Hungary), imposing limits on accepted migrants (Austria), encouraging voluntary leaving (Germany, Austria, Sweden, Denmark), and refusing to accept any immigrants or refugees (Slovakia, Czech Republic, Poland, Hungary).

\section{What was the impact of taken actions?}

The actions taken by EU institutions proved inadequate in solving the migration crisis. The biggest failure was the relocation process. European Commission statistics show only 272 migrants were relocated at the end of $2015^{33}$. The other failure was the naval operation against people smuggling which was transformed

${ }^{33}$ According to the EU relocation program 160000 migrants were supposed to be relocated from Greece and Italy during two years (May 2015 - September 2017). Till September 2017, only 29000 people were relocated: EC, Fourteenth on Relocation and Resettlement, COM (2017), 405 final, Brussels 26.7.2017, p. 3. URL: https://ec.europa.eu/home-affairs/sites/homeaffairs/files/whatwe-do/policies/european-agenda-migration/20170726_fourteenth_report_on_relocation_and_resettlement_en.pdf, [access 1.08.2017]. 
into a rescue operation. Instead of fighting the smugglers, EU naval forces became their 'partners' in the transfer of illegal migrants to Europe. The attempts to reform the CEAS also faced strong opposition from member states. There is no consensus on the depth of reform. For some member states, the European Commission proposals go too far and interfere with state sovereignty. Full compliance of member states was achieved in the area of external border control. All EU members recognize the need to strengthen the external border and demonstrate the will to cooperate. It should be emphasized, however, that the highest impact on slowing down the migrant inflow to the EU was the decisions made by the states located along the Balkan route (Macedonia, Serbia, Hungary, Croatia, Slovenia and Austria) to close their borders to illegal migrants and, to a lesser extent, the agreement with Turkey.

\section{CONCLUSIONS}

The study was devoted to an analysis of the EU migration crisis from the perspective of the concept of non-traditional security. It argued that the 2015 wave of immigration to EU, due to its dynamics and scale, should be treated not only as a humanitarian or social challenge but also as a security one. Three general conclusions can be formulated.

First, in the process of dealing with the migration crisis, the key element is the way it is perceived. The analysis has shown that the more the crisis was perceived as a security threat, the greater the attention and willingness of states to cooperate. The empirical analysis has shown that states' willingness to cooperate increases when the proposed actions reflect the security dimension of the migration crisis. In the EU context, actions to strengthen border control, to establish European border and coast guards, to improve migrants' registration procedures and information sharing, or to solve the problem at its source have gained more support from all member states than a relocation mechanism that was perceived as a policy undermining national security

Second, the failure of regional responses to the migration crisis at the EU level does not necessary mean that the main NTS assumption about the effectiveness of regional solutions was incorrect. The analysis proved that states were more interested in regional actions that addressed interests such as security then they were in actions motivated purely by values such as human rights. Undoubtedly, national governments were more willing to engage in patterns that strengthen their security rather than to accept approaches undermining their national interests. States' willingness to cooperate in this context can be explained in terms of security interdependence, i.e., that in the face of the migration crisis they are not able to achieve their security goals individually. ${ }^{34}$ Therefore, the conceptualization

${ }^{34}$ M. Ceccorulli, Migration as a security threat: internal and external dynamic in the European Union, GARNET Working Paper no 65/09, p. 5. 
of the migration crisis as a non-traditional security threat has high 'explanatory potential' that can help understand the paradox between the need for regional solutions on the one hand and the reluctance to use them on the other.

Finally, a key factor encouraging or discouraging states to cooperate in solving non-traditional security threat lies in the perception of the problem and the character of proposed solutions - the more consistent with states' interests the more cooperation. In the EU case, an evolution of actions aiming to solve the migration crisis can be observed. It is symptomatic that keeping the rhetoric of the migration crisis as a humanitarian and human rights challenge did not lead to action; actions taken were based on the perception of its security dimensions. The containment of migrant flows was more important task than the protection of migrants.

Tytul: Kryzys migracyjny w Unii Europejskiej z 2015 roku jako niestandardowy problem bezpieczeństwa

Streszezenie: Celem artykułu jest analiza kryzysu migracyjnego w UE z 2015 roku z perspektywy niestandardowych problemów bezpieczeństwa. Podstawę rozważań stanowi teza, zgodnie z którą fala imigracji do UE, ze względu na dynamikę i skalę, stanowiła nie tylko wyzwanie humanitarne czy problem społeczny ale również zagrożenie dla bezpieczeństwa. Zgodnie bowiem z koncepcją niestandardowych problemów bezpieczeństwa, zjawiska takie jak nielegalna migracja, choroby zakaźne czy braki żywności, które do niedawna jedynie pośrednio wpływały na jego poziom, stanowią obecnie bezpośrednie zagrożenie dla przetrwania i rozwoju państw.

Słowa kluczowe: niestandardowe problemy bezpieczeństwa, kryzys migracyjny, Unia Europejska 